\title{
The Mark of Cain and White Violence
}

\author{
NYASHA JUNIOR \\ nyasha.junior@temple.edu \\ Temple University, Philadelphia, PA 19122
}

\begin{abstract}
Many interpreters have questioned the "mark" placed on Cain after he kills his brother Abel. The notion of the "mark of Cain" as dark skin is a familiar interpretive tradition. Less well known are interpretations that treat the mark as white skin. This article traces how Black interpreters connect the "mark of Cain," white skin, and White violence.
\end{abstract}

"Let me tell you something, man. There are Black people everywhere. Remember that, okay? No place you can go in the world ain't got no Black people. We was the first on this planet."

-Juan in Moonlight $(2016)^{1}$

In the book of Genesis, Cain kills his brother Abel (4:8), but the Lord places a "mark" on Cain so that no one will kill him (4:15b). ${ }^{2}$ Interpreters have offered numerous understandings of this mark, including the pervasive notion that the so-called mark of Cain resulted in the darkening of Cain's skin and that of his subsequent descendants. Less well known are interpretations of the mark as white skin. In this article, I trace the linkage of the "mark of Cain," white skin, and White violence by Black interpreters in the nineteenth and twentieth centuries. First, I provide background on the mark of Cain and interpretations of the mark as dark skin. Second, I discuss how some interpreters treated the mark as white skin. Third, focusing on Marcus Garvey, I examine efforts to connect white skin with Cain's killing of his brother. Scholars tend to treat "white-skin" interpretations as reactions to the "mark of Cain" as dark skin. Yet this interpretive tradition is less interested in explaining how some people became White than in why White people have violent tendencies. I argue that such "white-skin" interpretations treat Cain as the

I thank Jeremy Schipper for helpful assistance and feedback on earlier drafts of this article. In addition, I thank Julie Claassens for inviting me to present portions of this research at "The Power to Discriminate: Re-evaluating Perversion in the Hebrew Bible and Beyond" at Stellenbosch University in 2020.

${ }^{1}$ Juan, in Moonlight, directed by Barry Jenkins, story by Tarell Alvin McCraney (A24, 2016).

${ }^{2}$ Translations of biblical texts are from the NRSV unless otherwise specified. 
progenitor of White people as an explanation for the violence of White people. Although overlooked by the majority of scholars, these Black interpreters seek not only to counter anti-Black etiologies but to treat blackness as natural and whiteness as perverse.

\section{The Mark of Cain}

After Cain kills his brother Abel (Gen 4:8), God places a "mark" on Cain (4:15). The purpose of the mark is to prevent anyone who encounters Cain from killing him, but the text does not provide a description of this mark. The Biblical Hebrew word denoting the "mark" (אות) occurs throughout the Hebrew Bible to designate a wide range of indicators, including the sign of the covenant after the flood (Gen 9:12), circumcision as a sign of the covenant (Gen 17:11), a sign indicating that God has sent Moses (Exod 4:12), a sign of the instructions provided by God (Deut 6:8), and the pledge required by Rahab (Josh 2:12). ${ }^{3}$

While God places the mark on Cain for Cain's protection, some interpreters have understood this "mark of Cain" as a curse that darkened the skin of Cain and his descendants. ${ }^{4}$ Treating biblical creation narratives as historical, they regarded Adam and Eve as the progenitors of all creation. In order to support the theory of monogenesis, a single origin for humanity, some used Gen 4:15 to explain the origins of dark-skinned African peoples. Some interpreters linked the "mark of Cain" with the so-called "curse of Ham" (Gen 9:20-27). ${ }^{5}$ Proslavery

${ }^{3}$ For surveys of scholarship on Cain and his mark, consult R. W. L. Moberly, "The Mark of Cain-Revealed at Last?," HTR 100 (2007): 11-28; and Claus Westermann, Genesis: A Commentary, trans. John Scullion, 3 vols. (Minneapolis: Augsburg, 1984-1986), 1:312-14. On interpretations of Cain, consult James L. Kugel, "Cain and Abel in Fact and Fable: Genesis 4:1-16," in Hebrew Bible or Old Testament? Studying the Bible in Judaism and Christianity, ed. Roger Brooks and John J. Collins, CJAn 5 (Notre Dame, IN: University of Notre Dame Press, 1990), 167-90; and Ricardo J. Quinones, The Changes of Cain: Violence and the Lost Brother in Cain and Abel Literature (Princeton: Princeton University Press, 1991).

${ }^{4}$ For interpretations of the mark of Cain as the origin of African peoples, consult David M. Goldenberg, Black and Slave: The Origins and History of the Curse of Ham, SBR 10 (Berlin: de Gruyter, 2017), 40-42, 153-55, 238-49; Goldenberg, The Curse of Ham: Race and Slavery in Early Judaism, Christianity, and Islam (Princeton: Princeton University Press, 2003), 178-82; and Ruth W. Mellinkoff, The Mark of Cain, Quantum Books (Berkeley: University of California Press, 1981), 76-80.

${ }^{5}$ In Gen 9, Ham sees the nakedness of his father Noah and tells his brothers Shem and Japheth. When Noah learns what Ham has done, he does not curse Ham but Ham's son Canaan (v. 25). Even so, the text is usually called the "curse of Ham." On this "curse of Ham," consult Rebecca Alpert, "Translating Rabbinic Texts on the Curse of Ham: What We Learn from Charles Copher and His Critics," in Re-presenting Texts: Jewish and Black Biblical Interpretation, ed. W. David Nelson and Rivka Ulmer, Judaism in Context 16 (Piscataway, NJ: Gorgias, 2013), 29-41; Stacy Davis, This Strange Story: Jewish and Christian Interpretation of the Curse of Canaan from 
advocates employed both texts in arguments supporting the enslavement of African peoples. ${ }^{6}$

While the "mark of Cain" as a curse of dark skin is a well-known interpretive tradition, some Black interpreters regard White people as the descendants of an originally Black Cain. This tradition holds that Cain turned white with fear after killing Abel or after God confronted him over the death of Abel. Some White informants report hearing such traditions from African peoples. For example, in 1836 Francis John Harrison Rankin published an account of his travels to West Africa during 1834. Rankin offered the European view of humanity's origins and countered with African perspectives.

We are taught to picture the Evil one as black. The African is certain that Satan is white. White physiologists may assert that mankind was originally fair, but that a torrid sun has darkened many of Adam's descendants. Black physiologists take a different view, and state our race to have been at first black. Cain, the first murderer was a negro, say they; but he became so pale with fear and remorse, that his colour never returned; and that leprous whites so abhorrent, so disgusting, stamped as a lasting mark upon his face, distinguished him and his descendants forever. ${ }^{7}$

In A Brief History of the Wesleyan Missions on the West Coast of Africa (1851), William Fox, a White missionary, related a story heard from Africans that Cain was a "Negro; but he became so pale with fear and remorse when he had murdered his brother, that his color never returned." Similarly, William Winwood Reede, a

Antiquity to 1865 (Lanham, MD: University Press of America, 2008); and Justin Michael Reed, "The Injustice of Noah's Curse and the Presumption of Canaanite Guilt: A New Reading of Genesis 9:18-29" (PhD diss., Princeton Theological Seminary, 2020). For interpretations of this curse and its connections to race, consult Jeremy Schipper, "Religion, Race, and the Wife of Ham," $J R$ 100 (2020): 386-401; Schipper, "The Blessing of Ham: Genesis 9:1 in Early African American Scholarship," BibInt (forthcoming); Sylvester A. Johnson, The Myth of Ham in Nineteenth-Century American Christianity: Race, Heathens, and the People of God, Black Religion, Womanist Thought, Social Justice (New York: Palgrave Macmillan, 2004); and Thomas Virgil Peterson, Ham and Japheth: The Mythic World of Whites in the Antebellum South, ATLA Monograph Series 12 (Metuchen, NJ: Scarecrow, 1978).

${ }^{6}$ On the curse of Ham and issues related to enslavement, consult Goldenberg, Curse of Ham; Goldenberg, Black and Slave; Stephen R. Haynes, Noah's Curse: The Biblical Justification of American Slavery (New York: Oxford University Press, 2002); and David M. Whitford, The Curse of Ham in the Early Modern Era: The Bible and the Justifications for Slavery, St Andrews Studies in Reformation History (Burlington, VT: Ashgate, 2009).

${ }^{7}$ F. Harrison Rankin, The White Man's Grave: A Visit to Sierra Leone, in 1834, 2 vols. (London: Bentley, 1836), 1:50-51.

${ }^{8}$ William Fox, A Brief History of the Wesleyan Missions on the West Coast of Africa: Including Biographical Sketches of All the Missionaries Who Have Died in That Important Field of Labour, with Some Account of the European Settlements and of the Slave-Trade (London: Aylott \& Jones, 1851), 12. 
British author and traveler, offered the following account mimicking the vernacular of a native preacher in Sierra Leone:

My breddren, you see white man bad too much, ugly too much, no good. You want sabby how man like dat come to lib in the world. Well, I tell you. Adam and Eve, dey coloured people, very han-sum; lib in one beautiful garden. Dere dey hab all things dat be good. Plantains, yams, sweet potatoes, foo-foo palm-winehe-igh, too much! Den dey hab two childrum, Cain and Abel. Cain no like Abel's palaver; one day he kill'm. Den God angry, and he say-Cain: Cain go hide himself; he tink him berry claber, Heigh-heigh! God say again-Cain, you tink I no see you, you bush-nigger-eh? Den Cain come out, and he say, "Yes, massa, I lib here-what de matter, massa?" Den God say in one big voice like de tunder in de sky, "Where'm broder Abel?" Den Cain turn white all ober with fear-dat de first white man, breddren. ${ }^{9}$

British traveler and prolific writer Sir Richard Francis Burton shared a tale from "converted negroes" in West Africa that "Cain was a black man, but when rebuked by the Creator for murder, he turned pale with fear: hence the white colour." ${ }^{10}$ In 1899, British writer and explorer Mary Kingsley reported on Africans familiar with "Muhammedan" tradition that held that, after killing Abel, Cain did not know how to hide the body and was "growing white" due to "horror and fear." Kingsley recounted, "All his children were white, and from Cain came the white races, while Abel's children are black, as all men were before the first murder." 12

Similar accounts were related by folklorists and others documenting tales from Africans in the United States. In 1899, Fanny Dickerson Bergen, an American folklorist, noted a version of the story that she heard in Maryland. This version reads, "White people are descendants of Cain. All mankind was once black, but when the Lord asked Cain where Abel was, Cain turned white with fright and so remained." ${ }^{13}$ In 1926, Newbell Niles Puckett, a White sociologist from Mississippi, credited Hattie Harris of Columbus, Mississippi, with a version of the story. Puckett

${ }^{9}$ William Winwood Reade, Savage Africa: Being the Narrative of a Tour in Equatorial, Southwestern, and Northwestern Africa; With Notes on the Habits of the Gorilla, on the Existence of Unicorns and Tailed Men, on the Slave Trade, on the Origin, Character, and Capabilities of the Negro, and on the Future Civilization of Western Africa (London: Smith, Elder, 1864), 24-25.

${ }^{10}$ Richard Francis Burton, Wit and Wisdom from West Africa; or, A Book of Proverbial Philosophy, Idioms, Enigmas, and Laconisms (London: Tinsley Brothers, 1865), 124.

${ }^{11}$ Mary Henrietta Kingsley, West African Studies (London: Macmillan, 1899), 384. While Cain's killing of Abel appears in the Qur'an (5:27-32), Cain and Abel are not mentioned by name. Also, the Qur'an does not mention Cain's turning white with fear. God sends a crow that scratches the earth, and, seeing the crow, Cain realizes that he can bury his brother and thereby conceal his brother's nakedness.

${ }^{12}$ Ibid., 385. The biblical text does not indicate that Abel had children.

${ }^{13}$ Fanny D. Bergen, ed., Animal and Plant Lore: Collected from the Oral Tradition of English Speaking Folk, Memoirs of the American Folk-lore Society 7 (Boston: Houghton, Mifflin, 1899), 80. 
wrote, "Nature made Africans black, and ethnocentrism, based upon this natural feature, always declares in the African story that all men were at first made black, but that when Cain killed Abel he turned white from fear; and in Maryland and Mississippi at least, precisely the same belief survives." ${ }^{14}$ In addition, in 1926, Black American educator William Pickens published an account of a "Black Belt preacher" who detailed the development of the races.

Brudders an' sisters, de fust man whut de Lord made, been named Adam. De fust 'oman been named Eve. Dey had two chilluns, Cain an' Abel. De ma an' de pa an' all dem chilluns wuz black, wuz cullud fokes. Now, Cain wuz a bad Negro, allus shootin' an' cuttin' an' gamblin'. He wuz jealous uv his brudder Abel an' killed him one day in a 'spute ovah de bes' watermillion in de patch. Den de Lord come up behin' Cain and say, sez he: "Cain whar am dy brudder?” Dat Cain wuz a sassy Negro, so he don' turn 'roun' to see who 'tis, but jes' ansers up biggity: "Am I my brudder's keeper? I ain't got him in my pockets. I s'pose he's off somewhar shootin' craps." Den de Lord he spoke more angry-like: “Cain, whar am dy brudder?"Den dat Negro turn 'roun' an' he see it wuz de Lord, an' he got so skeered dat his hair stan' up right straight an' his face turn right pale,- - an' sisters an' brudders, dar am whar de fust white man come frum $!^{15}$

Unlike Pickens's account, some sources use stereotyped Black vernacular speech in an attempt at humor in recounting Cain's turning white. It is unclear if these sources are entirely fictitious or simply wildly and offensively embellished. The "Extract from Sambo's Sermon" (1828) reads:

Strate is de rode and narrer is de paff which leadeff to Glory. Brederen blevers! You semble dis nite to har de word, and hab it splained and monstrated to you; yes, and I ten for splain it clear as de lite ob de liben day. We're all wicked sinners har below-it's a fac, my brederen, and I tell you how it cum. You see, my frens, Adam was de fus man/ Ebe was de tudder/ Cane was a wicked man/ Kase he kill he brodder. Adam and Ebe were bofe brack men, an so was Cane and Abel. Now I spose it to strike your understandin how de fus white man cum. Wy, I let you no. Den you see when Cane kill his brodder, de massa cum an he say- "Cane whar you a brudder Abel!" Cane say, "I don't know massa." He cum gin an say, "Cane whar you a brodder Abel!" Cane say, "I don’t know massa." But de nigger noed all de time. Massa now git mad, cum gin, speak paoke mity sharp dis time. "Cane whar you a brodder Abel, you niggar!" Cane now git friten an he turn wite; and dis is de way de fus wite man cum pon dis arth! an if it had not been for dat dare

${ }^{14}$ Newbell Niles Puckett, Folk Beliefs of the Southern Negro (Chapel Hill: University of North Carolina Press, 1926), 4-5. Puckett credited Hattie Harris in the "list of informants" (599-604). He observed further that this story was similar to those recorded by Mary Kingsley and Fanny Dickerson Bergen.

${ }^{15}$ William Pickens, American Aesop; Negro and Other Humor (Boston: Jordan \& More, 1926), 23 (emphasis original). 
niggar Cane, we'd neba been troubled wid dese sassy wites pon de face of dis circumlar globe. Now sing de forty-lebenth hymn ticular metre. ${ }^{16}$

In 1886, Maria Remington Hemiup argued that the view that Black people were the first humans reflected "a poor and ignorant colored man's reasoning." She explained:

His reasoning from cause to effect evinces the character of a philosopher, even though he is unlettered. "God made our first parents black," he said, "all d'er chilun were black. Cain was black, den he slewed his bruder Abel; and de Lord said (awful loud), 'Cain what did you do dat for?' Cain was awful scared! He trembled all over, and de Lord looked so awful sharp at Cain dat it scared him white; and dat am how Cain's posterity came to be white!"17

In 1887, English humorist John Bernard attributed the following poem to a presumably fictitious text titled History and Metaphysics of Negroland by a fictitious author named Sambotius Quamina: "When Garra Mighty see urn dead, / Massa Cain in such a fright, / He tremble from him toe to head / And den he turn all white!"18

\section{Scholarship on White CaIN}

In Black Culture and Black Conscience (1977), historian Lawrence W. Levine cited several examples of African and African American folklore on Cain as the progenitor of White people. ${ }^{19}$ Since then, other scholars have cited Levine's sources

16 "Extract from Sambo's Sermon," Free Press [Tarborough, North Carolina], March 28, 1828, 4 (emphasis original). The line "Strate is de road and narrer is de paff which leadeff to Glory" is a paraphrase of Matt 7:14: "Because strait is the gate, and narrow is the way, which leadeth unto life, and few there be that find it" (KJV). Eston Everett Ericson quoted the "Extract from Sambo's Sermon" in an essay on folklore in the Tarborough Free Press, a weekly rural North Carolina newspaper (Ericson, "Folklore and Folkway in the Tarboro [N. C.] Free Press [1825-1850]," Southern Folklore Quarterly 5 [1941]: 124). Ericson describes the alleged sermon as one of two "humorous pourquoi ('why?') stories that are found in successive numbers [of the Free Press] in 1828. One tells why the white man is white, and the following week a correspondent answers with one as to why the negro is black" (ibid.).

${ }^{17}$ Maria Remington Hemiup, Law of Heat: Original Observations, Expansion of Ice in Harmony with the General Law, General Law of Heat in Connection with Hypothesis of Planetary Movement (Geneva, NY: Gazette Steambook, 1886), 108 (emphasis original).

${ }^{18}$ John Bernard, Retrospections of America, 1797-1811 (New York: Harper \& Brothers, 1887), 130.

${ }^{19}$ Lawrence W. Levine, Black Culture and Black Consciousness: Afro-American Folk Thought from Slavery to Freedom (New York: Oxford University Press, 1977), 85-86. In the main text, Levine quoted or summarized three sources: Burton, Wit and Wisdom from West Africa, 124; Kingsley, West African Studies, 384-85; and Hardin E. Taliaferro, Fisher's River (North Carolina) Scenes and Characters (New York: Harper, 1859), 188-89. In addition, without quotation, Levine cited several other sources (460 n. 9). Levine cites Ericson's article but not the "Extract 
(sometimes crediting Levine) and have provided additional versions of this story from other nineteenth- and early twentieth-century sources. ${ }^{20}$ Levine and others interpreted such folklore of an originally Black Cain as countering well-known understandings of the skin-darkening "mark of Cain." For example, Levine wrote, "The assumption of a black creation allowed slaves to stand the white creation myths on their heads." ${ }^{21}$ In 2006, historian Colin Kidd cited a version of the story told by Marcus Garvey and explained, "The black nationalist leader Marcus Garvey (1887-1940) inverted the white racist version of the mark of Cain."22 In 2017, after analyzing other anti-Black interpretations, David M. Goldenberg cited Levine and Kidd and argued, "In a reversal of colors, some stories told by Africans and AfricanAmerican former slaves see Cain as punished with white skin, and thus the origin of whites."23 Having listed Garvey alongside the versions cited by Levine, Goldenberg concluded, "All these stories, whether told by blacks about whites or by whites about blacks, are etiologies accounting for the 'unusual' skin color of the Other." ${ }^{24}$

Since Levine and other scholars treated this "Cain becomes White" folklore as countering the notion of the darkening mark of Cain, they read it primarily as a reaction or corrective to an anti-Black interpretive tradition regarding the mark of Cain. Yet, when read in context, these "Cain becomes White" interpretations are not focused on accounting for the skin color of White people but arguing for blackness as an original state of humanity. Furthermore, within this strand of tradition, some interpreters push further to explain why, in their view, White people are inherently violent. These interpreters read whiteness not as neutral but

from Sambo's Sermon" in Ericson, "Folklore and Folkway in the Tarboro (N. C.) Free Press (1825-1850)."

${ }^{20}$ For representative examples, consult Ernest Allen Jr., "Identity and Destiny: The Formative Views of the Moorish Science Temple and the Nation of Islam," in Muslims on the Americanization Path?, ed. Yvonne Yazbeck Haddad and John L. Esposito (New York: Oxford University Press, 2000), 163-214, here 169 n. 13; Mia Bay, The White Image in the Black Mind: AfricanAmerican Ideas about White People, 1830-1925 (New York: Oxford University Press, 2000), 123; and W. T. Lhamon Jr., Raising Cain: Blackface Performance from Jim Crow to Hip Hop (Cambridge: Harvard University Press, 1998), 118-20.

${ }^{21}$ Levine, Black Culture and Black Consciousness, 85.

${ }^{22}$ Colin Kidd, The Forging of Races: Race and Scripture in the Protestant Atlantic World, 1600-2000 (New York: Cambridge University Press, 2006), 35.

${ }^{23}$ Goldenberg, Black and Slave, 41-42. In Goldenberg's corresponding footnote (42 n. 55), he writes, "Levine, Black Culture, pp. 85-86 records several versions of this tale. The story was also told by Marcus Garvey; see Colin Kidd, Forging of Races, 35, and Mia Bay, The White Image in the Black Mind (Oxford, 2000), p. 123." Yet Bay did not mention Garvey in this context. Rather, she cited Levine as her only source to support her claim that, according to an "enduring Creation legend, white people came about as a result of Cain's fratricide, which made him pale with horror and fear" (Bay, White Image in the Black Mind, 123).

${ }^{24}$ Goldenberg, Black and Slave, 41-42. Here Goldenberg referred not only to skin etiologies based on the mark of Cain but also to those based on Adam, Miriam, Gehazi, and others. See, e.g., Num 12:10 and 2 Kgs 5:27 KJV; and see n. 29 below. 
as perverse and seek to explain why White people are violent. Focusing on Garvey, I demonstrate how Garvey reframed the "mark of Cain" within a Black interpretive tradition that has been overlooked in scholarly discussions of racialized interpretations of the mark of Cain.

\section{Black CAIN by BlaCk INTERPRETERS}

Marcus Garvey was a Jamaican-born Black nationalist who founded the Universal Negro Improvement Association in 1916. Committed to Pan-Africanism, he was a charismatic speaker, political activist, and newspaper editor, and he galvanized the early twentieth-century "Back to Africa" movement. ${ }^{25}$ In a speech delivered on 1 August 1922 at the Third Annual Convention of the Negro Peoples of the World in New York City, Garvey claimed that Cain killed Abel out of envy of his brother's success and a desire for his brother's property. Although his speech does not interpret Abel's murder as part of an origin story of White people, Garvey asserted that European nations exploit Africa in similar ways. He explained:

From the fall of Adam man became a rebellious, wicked, covetous, yes man from the time of Cain and Abel coveted the property of his brother man, became envious of his brother's success, yes, it was on the principle of injustice that Cain killed Abel, it is on the same principle of injustice that England exploits Africa, that France exploits Africa, that Italy exploits Africa, that Belgium exploits Africa, that the stronger nations of the world exploit the weak. ${ }^{26}$

While imprisoned in the Atlanta Federal Penitentiary in 1927, Garvey wrote "The Tragedy of White Injustice." In this epic poem, Garvey described the White race as inheriting Cain's bloodguilt and emerging from caves to steal the products of civilization developed in Africa.

Blood of murderer Cain is on their head,

Of man and beast they mean to kill dead ...

Out of cold old Europe these white men came,

From caves, dens, and holes, without any fame,

${ }^{25}$ On Marcus Garvey, consult Rupert Lewis, Marcus Garvey, Caribbean Biography Series (Kingston, Jamaica: University of the West Indies Press, 2018); and Adam Ewing, The Age of Garvey: How a Jamaican Activist Created a Mass Movement and Changed Global Black Politics, America in the World (Princeton: Princeton University Press, 2014).

${ }^{26}$ Marcus Garvey, "Whether We Will Accept Civilization as It Is or Put It under a Rigid Examination to Make It What It Ought to Be as Far as Our Race Is Concerned," in Selected Writings and Speeches of Marcus Garvey, ed. Bob Blaisdell (Mineola, NY: Dover, 2004), 87. Similarly, consult lesson 11 in the curriculum of Garvey's "School of African Philosophy" in which Garvey stated, "Cain killed Abel for his success" (Marcus Garvey, Life and Lessons: A Centennial Companion to The Marcus Garvey and Universal Negro Improvement Association Papers, ed. Barbara Bair and Robert A. Hill [Berkeley: University of California Press, 1987], 260). 
Eating their dead's flesh and sucking their blood,

Relics of the Mediterranean flood;

Literature, science and art they stole,

After Africa had measured each pole. ${ }^{27}$

Garvey argued that White people inherited Cain's murderous tendencies and that they survived with no civilization to speak of in the caves of Europe. Although both the 1922 speech and the 1927 poem associate Cain and White people with bloodshed, neither addresses Cain's encounter with God after he kills Abel. Yet, in lesson 12 of Garvey's 1937 "School of African Philosophy" curriculum, Garvey explicitly linked Cain's becoming white with fear and the inherent violence of White people. ${ }^{28}$ After Cain's encounter with God, he flees to "the land of Nod, on the east of Eden" (Gen 4:16). Building on this text, Garvey declared,

When Cain slew Abel and God appeared to ask for his brother he was so shocked that he turned white, being the affliction of leprosy and as such, he became the progenitor of a new race out of double sin. The white man is Cain transformed, hence his career of murder from Cain to Mussolini. It is evident and fair assumption that when Cain ran away and disappeared from the neighbourhood of his parents and journeyed afar, he built up a new race, living in the same country but far away, and in the process of time in Africa, where all this happened, the Negro race, through Adam and Eve continued their multiplication and as it spread itself in the development of a civilisation, it came suddenly upon the settlement of Cain and knowing Cain's history of blood ran the entire race from that neighbourhood across the Mediterranean into Europe. The white race of Cain hid in caves for centuries. Therefore, their white skin became fixed as most of the time they were hidden from the light. Hence, the white man as a European. ${ }^{29}$

${ }^{27}$ Marcus Garvey, "The Tragedy of White Injustice," in The Poetical Works of Marcus Garvey, ed. Tony Martin, New Marcus Garvey Library 2 (Dover, MA: Majority Press, 1983), 4. The lines "Eating their dead's flesh and sucking their blood / Relics of the Mediterranean flood" may allude to the idea that the descendants of Cain survived the flood by escaping to Europe because the flood was limited to areas known to the biblical authors. On the idea of survivors of a limited flood, consult Kidd, Forging of Races, 64, 71, 88-89, 134-35.

${ }^{28}$ Garvey taught this course to four women and seven men who became regional commissioners of Garvey's Universal Negro Improvement Association upon graduation. The next year, Garvey offered the lessons to people of African descent as a correspondence course available through mail order for a fee of twenty-five dollars. On Garvey's "School of African Philosophy," consult Bair and Hill, Marcus Garvey, Life and Lessons, xlix; and Charles L. James, "Foreword," in Message to the People: The Course of African Philosophy, ed. Tony Martin, New Marcus Garvey Library 7 (Dover, MA: Majority Press, 1986), ix-xiii, here x-xii.

${ }^{29}$ Bair and Hill, Marcus Garvey, Life and Lessons, 269. According to the KJV, which was the translation that Garvey used, "Miriam became leprous, white as snow" (Num 12:10), and Gehazi became "a leper as white as snow" (2 Kgs 5:27). Often scholars note that, unlike the KJV, Num 12:10 and 2 Kgs 5:27 in the MT simply read "like snow" and do not include the word for "white." For example, Emerson B. Powery and Rodney S. Sadler Jr. explain, "The Hebrew text does not include the adjective 'white'; nevertheless, the KJV continues to influence many translations, 
According to Garvey, the White race ended up in Europe because Cain's White descendants were driven out of Africa by the Black descendants of Adam and Eve who knew of Cain's violence. Garvey credited the Black descendants of Adam and Eve living in Africa with developing civilizations while the White descendants of Cain hid in caves in Europe. Although Garvey explained Cain's transformation into a White man as the result of shock and leprosy, he focused on how White people inherit Cain's violent nature. ${ }^{30}$ In doing so, he provided an origin story for their skin color and geographic location.

For Garvey, White people share Cain's envy and greed, which Garvey understood as the primary motives for Cain's murder of Abel. By contrast, the versions of the story of Cain turning white with fear do not emphasize the idea of the White

including the NRSV translation of 2 Kings 5:27: 'So he left his presence leprous, as white as snow.' One recent translation, the Common English Bible, alters the color analogy: 'And Gehazi left Elisha's presence, flakey like snow with skin disease"' (The Genesis of Liberation: Biblical Interpretation in the Antebellum Narratives of the Enslaved [Louisville: Westminster John Knox, 2016], 104 n. 87). By contrast, "white" (לבן) appears in Hebrew in Isa 1:18, which the KJV translates as "they shall be as white as snow" and in Ps 51:7 (v. 9 in Hebrew), which the KJV translates as "I shall be whiter than snow."

${ }^{30}$ Garvey's reference to Cain's whiteness as "the affliction of leprosy" draws on earlier notions that biblical characters with leprosy were the progenitors of the White race. These notions are attested in literature by persons of African descent but not in the biblical story of Cain. The idea that God marked Cain with what is often mistranslated as "leprosy" is attested in early Jewish literature (Gen. Rab. 22:12). Consult Louis Ginzberg, The Legends of the Jews, 7 vols. (Baltimore: Johns Hopkins University Press, 1998 [originally published by the Jewish Publication Society of America, 1909-1938]), 1:112, 5:141 n. 28; Mellinkoff, Mark of Cain, 20. On צרעת, often mistranslated as "leprosy," consult Jacob Milgrom, Leviticus 1-16: A New Translation with Introduction and Commentary, AB 3A (New York: Doubleday, 1991), 816-24. In the KJV, used by Garvey, skin that has become what is translated as "leprous" is repeatedly described as "white" (Lev 13:4, 10, 13, 16, $17,19,20,24,28,39,42,43)$. Thus, it is unsurprising that Garvey associated white skin with leprosy. Garvey was not the only Black leader to claim that God turned Cain into a leper. According to Hans A. Baer, in 1938 Father George Willie Hurley, who founded the Universal Hagar's Spiritual Church in Detroit in 1923, claimed that "Whites are the offspring of Cain, who had been cursed with a pale color because of leprosy" (Hans A. Baer, The Black Spiritual Movement: A Religious Response to Racism [Knoxville: University of Tennessee Press, 1984], 94). The idea that biblical texts involving "leprosy" served as origin stories for the White race was well established by the 1930s. For example, in William J. Anderson's 1857 autobiography, he wrote, "Gehazi was scared, and he went out from the Prophet white as snow. We perceive, therefore, that there have been white men ever since that time" (Life and Narrative of William J. Anderson Twenty-Four Years a Slave, or: The Dark Deeds of American Slavery Revealed; Also a Simple and Easy Plan to Abolish Slavery in the United States, together with an Account of the Services of Colored Men in the Revolutionary War, Day and Date, and Interesting Facts [Chicago: Daily Tribune Book and Job Printing Office, 1857], 61-62). On Anderson's interpretation of Gehazi, leprosy, and race, consult Powery and Sadler, Genesis of Liberation, 102-9. For other interpretations of Gehazi, Miriam, leprosy, and race by persons of African descent, consult the discussions and citations in Allen, "Identity and Destiny," 169 n. 13; Bay, White Image in the Black Mind, 214; Goldenberg, Black and Slave, 42 n. 56; and Kidd, Forging of Races, 265. 
race's propensity for envy and greed as evidence of their connection to Cain. One cannot account for this aspect of Garvey's version by suggesting that he is simply repeating folklore that reacts to anti-Black interpretations of the mark of Cain. Rather, Garvey was incorporating the folklore that Cain turned white with fright into a different interpretive tradition of Cain's murder of Abel as an explanation for White violence that was originally unrelated to his fearful confrontation with God.

Garvey was not the first Black interpreter to connect Cain's whiteness with violence. In 1814, Pompée-Valentin de Vastey published Le système colonial dévoilé (The Colonial System Unveiled). Vastey was a Haitian intellectual whose father was French and whose mother was Haitian. Occasionally utilizing biblical texts, Vastey offered a scathing critique of colonialism and slavery before the Haitian Revolution (1791-1804). For example, he noted that some interpreters trace "the color of the blacks" (la couleur des noirs) to Noah's curse in Gen 9:25-27.

Others affirm that our colour and our reprobation can be traced back to Cain, for killing his brother Abel. I have strong reasons for believing that it is actually the whites who are of the race of Cain, for I find in them that primitive hatred, that spirit of envy and arrogance, and that passion for riches of which scripture speaks, and which led him to sacrifice his brother. ${ }^{31}$

Vastey did not mention the idea that Cain's divine encounter turns him white with fear. Instead, Vastey anticipated Garvey's later characterization of Cain and his White descendants as envious and greedy. It is not their external appearance but their internal characteristics that connect White people with Cain.

David Walker, a Black abolitionist, made an argument similar to Vastey's in Walker's Appeal to the Colored Citizens of the World (1829), in which he attacked the institution of slavery. ${ }^{32}$

I have searched the Bible as well as they, if I am not as well learned as they are, and have never seen a verse which testifies whether we are the seed of Cain or of Abel. Yet those men tell us that we are the seed of Cain, and that God put a dark stain upon us, that we might be known as their slaves!!! Now, I ask those avaricious and ignorant wretches, who act more like the seed of Cain, by murdering, the whites or the blacks? How many vessel loads of human beings, have the blacks thrown into the seas? How many thousand souls have the blacks murdered in cold blood, to make them work in wretchedness and ignorance, to support them and their families?"33

${ }^{31}$ Baron de Vastey, The Colonial System Unveiled, ed. and trans. Chris Bongie (Liverpool: Liverpool University Press, 2014), 104.

${ }^{32}$ For a detailed discussion of David Walker and his Appeal, consult Peter P. Hinks, To Awaken My Afflicted Brethren: David Walker and the Problem of Antebellum Slave Resistance (University Park: Pennsylvania State University Press, 1997).

${ }^{33}$ David Walker, Walker's Appeal, in Four Articles, Together with a Preamble to the Colored Citizens of the World, but in Particular, and Very Expressly to those of the United States of America; 
Like Vastey, Walker acknowledged that some have claimed that people of African descent are the "seed of Cain" because supposedly "God put a dark stain upon us." Yet he countered that White people "act more like the seed of Cain" because of their murderous ways.

This link between Cain and White people on the basis of similar behavior appears in the work of other abolitionists. ${ }^{34}$ In November 1835, the abolitionist newspaper The Anti-Slavery Record published selected paragraphs of Vastey's Colonial System Unveiled in English translation under the title "Which of the Races Is Descended from Cain?"35 Throughout the nineteenth century, this translation of Vastey's comments about Cain was reprinted in various African American newspapers and literature. For example, in the 1844 edition of his book Light and Truth, Black and indigenous writer Robert Benjamin Lewis quoted the entire paragraph. ${ }^{36}$ Formerly enslaved African American abolitionist Henry Bibb also quoted Vastey in "To Our Old Masters," in Voice of the Fugitive, 12 February $1851^{37}$ Vastey's text also appeared in an article titled "A Knotty Problem" in the African American newspaper Langston City Herald, 13 April 1895. ${ }^{38}$

Read against this backdrop, Garvey's references to Cain reflect a clear understanding of White people as linked to Cain through a shared tendency toward envy, greed, and murder. Nonetheless, recent scholarly discussions of Cain as the progenitor of the White race cite Garvey's 1938 interpretation of Cain without acknowledging Garvey's previous discussions of Cain or earlier writers of African descent, such as Vastey and Walker. Such scholarship catalogues Garvey's interpretation as simply another example of "white with fear" readings. Yet Garvey and others were not attempting solely to counter anti-Black interpretations of the mark of Cain. Instead, they argued that Cain was the progenitor of White people to provide the origin point of a long history of White violence.

Written in Boston, in the State of Massachusetts, Sept. 28, 1829, 2nd ed., with corrections (Boston: D. Walker, 1830), 63-64.

${ }^{34}$ On the reception of Vastey among African Americans in the nineteenth century, consult Chris Bongie, "Introduction," in Vastey, Colonial System Unveiled, 27-80, here 79 n. 53.

35 "Which of the Races Is Descended from Cain?," The Anti-Slavery Record, 1.11, November 1835, 9-10, here 10. Unlike Vastey's French text, the 1835 English translation that was circulated throughout the nineteenth century includes the term mark when describing how God punished Cain for the murder of Abel.

${ }^{36}$ Robert Benjamin Lewis, Light and Truth: Collected from the Bible and Ancient and Modern History, Containing the Universal History of the Colored and the Indian Race from the Creation of the World to the Present Time (Boston: Published by a Committee of Colored Gentlemen, Benjamin F. Roberts, Printer, 1844), 326. This Cain reference is not in the 1836 edition of Light and Truth.

${ }^{37}$ Henry Bibb, “To Our Old Masters" (Jan-Feb 1851), in The Black Abolitionist Papers, ed. C. Peter Ripley, 5 vols. (Chapel Hill: University of North Carolina Press, 1986), 2:125.

38 "A Knotty Problem," Langston City Herald, 13 April 1895, 1. 


\section{Conclusion}

In his 1963 classic, The Fire Next Time, James Baldwin wrote, "In the same way that we, for white people, were the descendants of Ham, and were cursed forever, white people were, for us, the descendants of Cain."39 Scholarly discussions on racialized interpretations of the mark of Cain have tended to group together Black interpretations of White Cain. In general, they have not differentiated folklore regarding an originally Black Cain who turns white with fear and treatments of a Cain who is understood as progenitor of White people who are violent like their ancestor. Furthermore, scholars have neglected to acknowledge that neither interpretation is merely a reaction to anti-Black etiologies. Black biblical interpreters have their own concerns and interests and are not solely writing in response to White interpreters. ${ }^{40}$ By regarding Black interpretations of White Cain as without tradition or unmoored from other African diasporic traditions, scholars have neglected an important strand of interpretation regarding the "mark of Cain."

${ }^{39}$ James Baldwin, The Fire Next Time (New York: Dial, 1963; repr., New York: Vintage International, 1993), 40-41.

${ }^{40} \mathrm{On}$ the development of womanist biblical interpretation as more than a by-product of feminist biblical interpretation, consult Nyasha Junior, An Introduction to Womanist Biblical Interpretation (Louisville: Westminster John Knox, 2015). 